\title{
Notes on the identity and taxonomy of Ixora cuneifolia and I. notoniana and typification of three names in Ixora
}

\author{
P. Murugan ${ }^{1 *}$, C. Murugan ${ }^{1} \&$ K. Karthigeyan ${ }^{2}$ \\ ${ }^{1}$ Botanical Survey of India, Southern Regional Centre, TNAU campus, \\ Coimbatore - 641003, Tamil Nadu, India \\ *murulax@gmail.com \\ ${ }^{2}$ Central National Herbarium, Botanical Survey of India, P.O. Botanic Garden, \\ Howrah - 711103, West Bengal, India
}

\begin{abstract}
Ixora predeepii Balan \& S.Harikr. and Ixora sivarajiana Pradeep are synonymised under Ixora cuneifolia Roxb. and Ixora notoniana Wall. ex G.Don respectively. Lectotypes are designated for the names Ixora nigricans R.Br. ex Wight \& Arn. and Ixora undulata Roxb. ex $\mathrm{Sm}$. A second step lectotype is designated for the name Ixora cuneifolia Roxb.
\end{abstract}

Keywords. India, lectotype, protologue, Rubiaceae, synonym, syntype, Western Ghats

\section{Introduction}

The genus Ixora L. is one of the largest genera in the tribe Ixoreae, subfamily Ixoroideae, family Rubiaceae (Bremer \& Eriksson, 2009), with 530-576 species distributed worldwide (Davis et al., 2009; POWO, 2021). The centre of species diversity for the genus is Southeast Asia (Lorence et al., 2007). It is easily distinguished from other genera of Rubiaceae by its arborescent habit, articulate petioles, tetramerous flowers, exserted stamens, 2-celled ovary with uni-ovulate locules, drupaceous fruits, and seeds with a large adaxial hilar cavity (De Block, 2008; Mouly et al., 2009). In India, the genus is represented by 47 species of which 21 species are endemic (Nayar et al., 2014; Singh et al., 2015; Kottaimuthu, 2016). As part of revisionary studies in the family Rubiaceae in the Southern Western Ghats of Kerala and Tamil Nadu, specimens of two Ixora species were collected during the period 2019 to 2021 from four different localities. In the process of identifying these collections, questions were raised as to the status of two recently described Ixora species, I. predeepii Balan \& S.Harikr. and I. sivarajiana Pradeep. The two names Ixora nigricans R.Br. ex Wight \& Arn. and Ixora undulata Roxb. ex Sm. are lectotypified. A second step lectotypification is done for the name Ixora cuneifolia Roxb.

\section{Materials and methods}

On consultation of the protologues, herbarium specimens and a perusal of literature (Husain \& Paul, 1989), the specimens collected were identified as Ixora cuneifolia Roxb. 
and Ixora notoniana Wall. ex G.Don. A critical study of the type specimens available at BR, CAL, CALI, E, FRC, K, KFRI, L, LE, LINN, MH, RHT and XCH and of relevant protologues (Smith, 1811; Roxburgh, 1820; Don, 1834; Pradeep, 1997; Balan \& Harikrishnan, 2016), led to the conclusion that two recently published species of the genus Ixora, I. predeepii Balan \& S.Harikr. and I. sivarajiana Pradeep are synonyms of I. cuneifoila Roxb. and I. notoniana respectively. In addition, we found that three names, Ixora cuneifolia Roxb., Ixora nigricans R.Br. ex Wight \& Arn. and Ixora undulata Roxb. ex Sm. have yet to be typified. Therefore, lectotypes are selected here in accordance with the rules of the Shenzhen Code (Turland et al., 2018). All specimens have been seen by the authors unless otherwise indicated; specimens examined via digital images are indicated with an asterisk (*).

\section{Taxonomic treatment}

Ixora cuneifolia Roxb., Fl. Ind. 1: 380 (1820). - TYPE: HBC [Cultivated in Calcutta Botanic Garden], Wallich s.n. [EIC 6140] (lectotype CAL [CAL0000069838], first step designated by Husain \& Paul (1989), second step designated here; isolectotypes CAL [CAL0000069836], K [K001123153*]). (Fig. 1)

Ixora predeepii Balan \& S.Harikr., Bangladesh J. P1. Taxon. 23(1): 65 (2016), syn. nov. - TYPE: India, Kerala, Idukki District, Udumbanchola, Myladumpara, $1100 \mathrm{~m}$, 10 November 2013, A.P. Balan 20471 (holotype MH [MH00003315]).

Shrubs up to $150 \mathrm{~cm}$ high; branchlets terete. Stipules triangular to subulate, up to 15 mm long, apex cuspidate, glabrescent. Leaves: lamina lanceolate, elliptic-lanceolate or oblong-lanceolate, 6-22 × 2-4 cm, cuneate at base, obtuse to acute or acuminate at apex, margins entire; lateral veins $8-15$ pairs; petioles 6-8 $\mathrm{mm}$ long, articulate. Inflorescence terminal, a corymbose panicle, trichotomously-branched, up to $6 \mathrm{~cm}$ long; peduncles slender, up to $5 \mathrm{~cm}$ long, puberulous. Flowers fragrant; bracts 2, opposite, boat-shaped, 4-6 mm long, sparsely puberulous; bracteoles 2, sub-opposite, lanceolate, 1-1.5 mm long, puberulous. Calyx tube up to $2 \mathrm{~mm}$ long, sparsely puberulous outside; lobes 4, linear-lanceolate, 1-1.5 mm long, ciliate, sparsely puberulous on outer surfaces. Corolla white with a tinge of pink, sometimes pale greenish white; tube 6-14 mm long, cylindrical; lobes 4, ovate, 4-5 mm long. Stamens 4; filaments very short; anthers pale yellow, linear-lanceolate, 3-4 mm long. Ovary globose, $<1 \mathrm{~mm}$ long; style filiform, up to $15 \mathrm{~mm}$ long; stigma bilobed, c. $2 \mathrm{~mm}$ long, linear. Drupes subglobose, $6-10 \times 6-8 \mathrm{~mm}$, green to slightly yellow turning bright red or scarlet red when ripe. Seeds 1 or 2, plano-convex or oval, 5-6 $\times 5-6 \mathrm{~mm}$, brown.

Distribution. Bangladesh, Myanmar and India (Karnataka, Kerala, Tamil Nadu, West Bengal). 

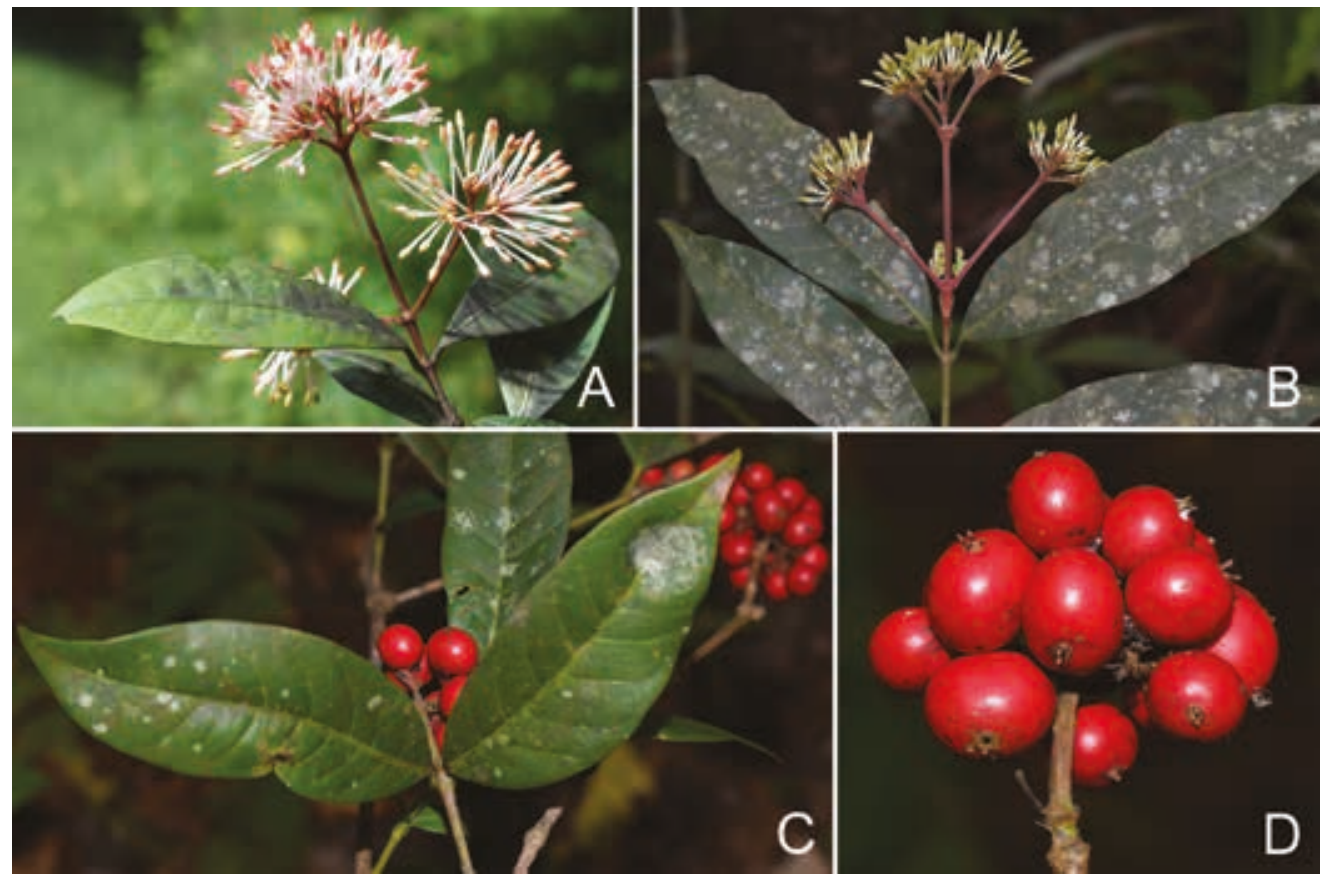

Fig. 1. Ixora cuneifolia Roxb. A, B. Flowering twigs. C, D. Fruiting twigs. (Photos: P. Murugan)

Phenology. Flowering from January to April and fruiting from August to September.

Specimens examined. INDIA: Kerala: Idukki District, Kulamavu to Painavu, Ghats Road, 700 m, 19 Dec 2020, Murugan 144936 (MH); Palakkad District, Singapara forest station on the way to Siruvani dam, 7 Jan 2021, Murugan 144955 (MH). Tamil Nadu: Coimbatore District, Anamalai Hills, Iyerpadi, \pm 1500 m, 17 Aug 2019, Murugan 144848 (MH).

Notes. In the protologue of Ixora cuneifolia, Roxburgh (1820) stated that it was a 'Native of the country Dacca' (now Dhaka, capital of Bangladesh). Husain \& Paul (1989) gave the type details as Wall. Numer. List no. 6140 at CAL. During the present study, we have traced eight specimens in different herbaria: three at CAL (CAL0000069836, CAL0000069837, CAL0000069838), four at K (K000031330, K001123152, K001123153, K001123154) and one at BR (BR0000005577644). Since there are three specimens at CAL, it cannot be ascertained which specimen at CAL was selected by them as the lectotype. Hence, we narrow down the designation here by selecting the specimen with the barcode CAL0000069838 in a second step lectotypification since it agrees well with the protologue.

Recently Balan \& Harikrishnan (2016) described the new species Ixora predeepii which we have found to be conspecific with Ixora cuneifolia as the type specimens and protologues match well. Therefore, Ixora predeepii is reduced here to a synonym of I. cuneifolia. 
Ixora notoniana Wall. ex G.Don, Gen. Hist. 3: 571 (1834). - TYPE: India, Nilgiris, R. Wight s.n. [EIC 6132] (lectotype CAL [CAL0000069740], designated by Husain \& Paul (1989)). (Fig. 2)

Ixora saulierei Gamble, Bull. Misc. Inform. Kew 1920: 247 (1920). - TYPE: India, Tamil Nadu, Madurai District, Pulney Hills, 1914, Rev. A. Sauliere 684 (lectotype MH [MH00002199], designated by Husain (1989)).

Ixora sivarajiana Pradeep, Nordic J. Bot. 17(3): 315 (1997), syn. nov. - TYPE: India, Kerala, Kozhikode District, Vellarimala, 2240 m, 10 April 1995, A.K. Pradeep 5365 (holotype K [K000031358*]; isotypes BRIT [BRIT23739*], CALI, MH [MH00000534]).

Small trees, 5-8 m tall; bark pale yellowish brown, sparsely fissured; branchlets terete. Stipules broadly ovate, 6-10 mm long. Leaves in whorls of 3 or 4; lamina narrowly elliptic-obovate, oblong-lanceolate or broadly oblong, $8-20 \times 3-8 \mathrm{~cm}$, usually narrowed to rounded or sometimes cuneate at base, acute to shortly mucronate at apex, margins entire; lateral veins $12-16$ pairs; petioles up to $2.5 \mathrm{~cm}$ long. Inflorescence axillary or terminal, a corymbose panicle, trichotomously-branched, $2-16 \mathrm{~cm}$ long; peduncles terete, $6-14 \mathrm{~cm}$ long, stout, puberulous. Flowers scented; bracts 2, opposite, obovate, 6-8 mm long; bracteoles 2, subopposite, linear-lanceolate, 4-7 mm long. Calyx tube $1 \mathrm{~mm}$ long; lobes 4, lanceolate, 1.5-2 mm long. Corolla usually brick red, scarlet or often white; tube 6-20 mm long; lobes 4, oblong, 4-5 mm long, apex obtuse, deflexed. Stamens 4; filaments very short; anthers lanceolate, 2-3 mm long. Ovary ovoid, c. $1 \mathrm{~mm}$ long; style 8-20 mm long, slender; stigma usually undivided or rarely bifid. Drupes subglobose, $8-12 \times 7-9 \mathrm{~mm}$, green to dark purple turning scarlet red. Seeds 1 or 2, hemispherical, 5-8 $\mathrm{mm}$ in diam., brown.

Distribution. India (Karnataka, Kerala, Tamil Nadu) and Sri Lanka.

Phenology. Flowering from December to June and fruiting from August to October.

Specimens examined. INDIA: Kerala: Idukki District, Marayoor, Kanthalloor forest range, Indragandhi malai, 1746 m, 6 Feb 2021, Murugan 144986 (MH); Wayanad District, Meppadi, 900 forests, 1735 m, 8 May 2019, Murugan 144830 (MH). Tamil Nadu: Nilgiris District, Naduvattam, 2000 m, 29 Feb 2020, Murugan 144885 (MH).

Notes. Wallich (1828-1849) listed 'Ixora notoniana' in A Numerical List of Dried Specimens of Plants in the East India Company's Museum, Collected Under the Superintendence of Dr. Wallich of the Company's Botanic Garden at Calcutta but the name is invalid since he did not provide a diagnosis or description. Later, Don (1834) subsequently validated the name, citing 'Wall. Cat. n. 6132, native of the East Indies, on the Nillghery Mountains'. Husain \& Paul (1989) gave the type details as Nilgiris, R. Wight in Wall. Num. List 6140 at CAL. Pradeep (1997) described a new 


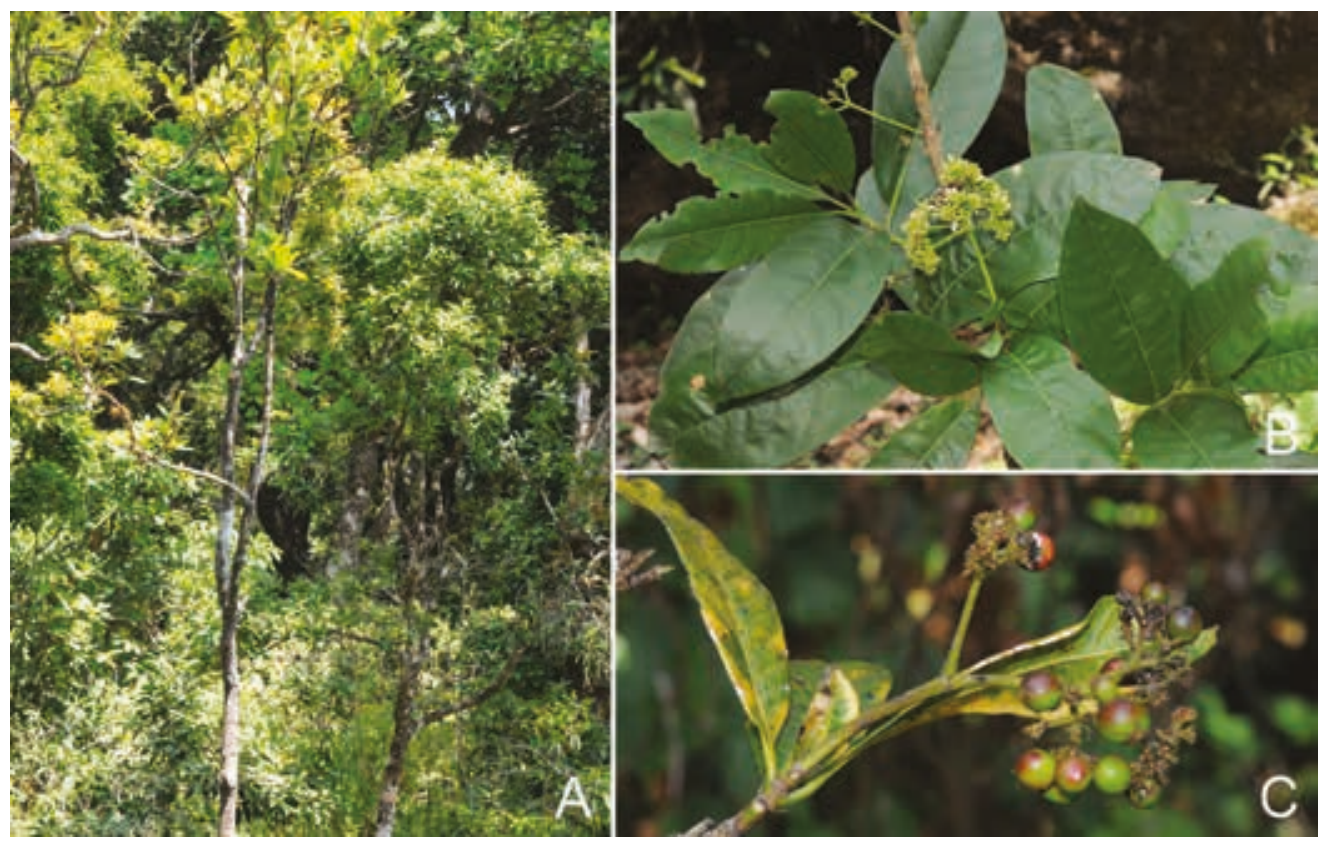

Fig. 2. Ixora notoniana Wall. ex G.Don. A. Habit. B. Flowering twig. C. Fruiting twig. (Photos: V. Ravichandran)

species as Ixora sivarajiana based on his collections from Vellarimala, Kozhikode, Kerala which unambiguously matches the type specimens and protologue of Ixora notoniana. Therefore, Ixora sivarajiana is reduced here to a heterotypic synonym of Ixora notoniana Wall. ex G.Don.

Ixora nigricans R.Br. ex Wight \& Arn., Prodr. Fl. Ind. Orient. 1: 428 (1834). TYPE: 'Peninsula Ind. Orientalis', R. Wight s.n. [Herb. Wight Propr. 1335] (lectotype E [E00174819*], designated here; isolectotypes BR [BR0000005587209*], E [E00174820*, E00174822*], LE [LE00017485*]).

Distribution. India (Andaman \& Nicobar Islands, Assam, Arunachal Pradesh, Karnataka, Kerala, Maharashtra, Meghalaya, Nagaland, Tamil Nadu, Tripura, West Bengal) and Myanmar.

Notes. Brown (1831-1832) proposed Ixora nigricans in the Wallich catalogue (18281849 ) as '6154, Ixora nigricans Brown', but the name was not validly published. Wight \& Arnott (1834) subsequently validated the name, citing 'Brown in Wall. ! L. n. 6154; Wight! cat. n. 1335'. We have traced 24 specimens of these collections in different herbaria, three at BR (BR0000005577651, BR0000005577989, BR0000005587209), six at CAL (CAL0000069731, CAL0000069732, CAL0000069733, CAL0000069734, CAL0000069735, CAL0000069736), six at E (E00174819, E00174820, E00174821, 
E00174822, E00174823, E00174829), six at K (K000031325, K000763217, K001123180, K001123181, K001123182, K001123183), two at LE (LE00017485, LE00017486) and one at L (L0535790). Among these, the specimen E00174819, a Wight specimen, is the best preserved and most complete, hence it is designated here as the lectotype of Ixora nigricans.

Ixora undulata Roxb. ex Sm. in Rees, Cycl. 19: 655 (1811). - TYPE: East Indies, 1808, Lord Valentia s.n. [Herb. Smith 189.9] (lectotype LINN [microfiche], designated here).

Distribution. India (Andaman \& Nicobar Islands, Andhra Pradesh, Assam, Arunachal Pradesh, Meghalaya, Odisha, Tamil Nadu, Tripura, West Bengal), Bangladesh, Nepal and Myanmar.

Notes. Smith (1811) in the protologue of Ixora undulata, cited the type information as 'East Indies via Lord Valentia'. The specimen Smith received is in his herbarium now in LINN. Husain \& Paul (1989) referred to the type of Ixora undulata as Roxburgh s.n. at $\mathrm{K}$ of which they had seen a photograph in CAL. It is very much doubtful that it represents material available to Smith before 1811 .

ACKNOWLEDGEMENTS. The authors are thankful to Dr A.A. Mao, Director, Botanical Survey of India, Kolkata, for constant support and encouragement and Dr M.U. Sharief, Scientist-E \& Head of Office, Botanical Survey of India, Southern Regional Centre, Coimbatore for providing facilities. They are grateful to the curators of BR, CAL, CALI, E, FRC, K, KFRI, L, LE, LINN, MH, RHT and XCH herbaria for providing images or access to consult herbarium specimens. The authors express their sincere gratitude to Dr David Middleton, for his valuable inputs and comments. Thanks are due to the Forest Departments of Kerala and Tamil Nadu, India for permission and necessary help during the field study; and to the Ministry of Environment, Forest and Climate Change, Government of India, New Delhi, for financial support under the Flora of India project.

\section{References}

Balan, A.P. \& Harikrishnan, S. (2016). Ixora predeepii, a new species of Rubiaceae from Southern Western Ghats, India. Bangladesh J. Pl. Taxon. 23(1): 65-69.

Bremer, B. \& Eriksson, T. (2009). Time tree of Rubiaceae: phylogeny and dating the family, subfamilies, and tribes. Int. J. Plant Sci. 170(6): 766-793.

Brown, R. (1831-1832). Ixora nigricans. In: Wallich, N. (ed.) A Numerical List of Dried Specimens of Plants in the East India Company's Museum, Collected Under the Superintendence of Dr. Wallich of the Company's Botanic Garden at Calcutta. p. 210. London. 
Davis, A.P., Govaerts, R., Bridson, D.M., Ruhsam, M., Moat, J. \& Brummitt, N.A. (2009). Global assessment of distribution, diversity, endemism, and taxonomic effort in the Rubiaceae. Ann. Missouri Bot. Gard. 96: 68-78.

De Block, P. (2008). Synopsis of the uniflorous Madagascan Ixora (Rubiaceae) species belonging to section Microthamnus. Belg. J. Bot. 141: 141-156.

Don, G. (1834). A General History of the Dichlamydeous Plants, Comprising Complete Description of the Different Orders, vol. 3. London: J.G. \& F. Rivington et al.

Husain, T. \& Paul, S.R. (1989). Taxonomic studies on Indian species of genus Ixora L. (Rubiaceae). J. Econ. Taxon. Bot., Addit. Ser. 6: 1-205.

Kottaimuthu, R. (2016). Ixora ravikumarii, a new name for Ixora monticola Gamble (Rubiaceae: Ixoroideae). Phytotaxa 263(1): 79-80.

Lorence, D.H., Wagner, W.L., Mouly, A. \& Florence, J. (2007). Revision of Ixora (Rubiaceae) in the Marquesas Islands (French Polynesia). Bot. J. Linn. Soc. 155: 581-597.

Mouly, A., Razafimandimbison, S., Florence, J., Jérémie, J. \& Bremer, B. (2009). Paraphyly of Ixora and new tribal delimitation of Ixoreae (Rubiaceae): inference from combined chloroplast (rps16, rbcL, and trnT-F) sequence data. Ann. Missouri Bot. Gard. 96: 146160.

Nayar, T.S., Raziya Beegam A. \& Sibi. M. (2014). Flowering Plants of the Western Ghats India, vol. 1, Dicots. Thiruvananthapuram, Kerala: Jawaharlal Nehru Tropical Botanic Garden and Research Institute.

POWO (2021). Plants of the World Online. Facilitated by the Royal Botanic Gardens, Kew. http://plantsoftheworldonline.org/. Accessed 8 Jun. 2021.

Pradeep, A.K. (1997). Ixora sivarajiana, a new species of Rubiaceae from India. Nordic J. Bot. 17: $315-317$.

Roxburgh, W. (1820). Flora Indica; or, Descriptions of Indian Plants, vol. 1. London: Allen $\&$ Co.

Singh, P., Karthigeyan, K., Lakshminarasimhan, P. \& Dash, S.S. (2015). Endemic Vascular Plants of India. Kolkatta: Botanical Survey of India.

Smith. J.E. (1811). Ixora. In: Rees, A. (ed.) The Cyclopaedia; or, Universal Dictionary of Arts, Sciences, and Literature, vol. 19. London: Longman, Hurst, Rees, Orme, Brown et al.

Turland, N.J., Wiersema, J.H., Barrie, F.R., Greuter, W., Hawksworth, D.L., Herendeen, P.S., Knapp, S., Kusber, W.-H., Li, D.-Z., Marhold, K. et al. (eds) (2018). International Code of Nomenclature for algae, fungi, and plants (Shenzhen Code) adopted by the Nineteenth International Botanical Congress Shenzhen, China, July 2017. Regnum Vegetabile, vol. 159. Glashütten: Koeltz Botanical Books.

Wallich, N. (1828-1849). A Numerical List of Dried Specimens of Plants in the East India Company's Museum, Collected Under the Superintendence of Dr. Wallich of the Company's Botanic Garden at Calcutta. London.

Wight, R. \& Arnott, G.A.W. (1834). Prodromus Florae Peninsulae Indiae Orientalis, vol. 1. London: Purbury, Allen \& Co. 
